\title{
ASYMMETRIC CORTICAL HIGH SIGNAL ON DIFFUSION WEIGHTED-MRI IN A CASE OF CREUTZFELDT-JAKOB DISEASE
}

\author{
Ricardo Nitrini', Renata Areza-Fegyveres', Vilma R. Martins², \\ Rosa Maria R.P.S. Castro', Michele C. Landemberger², \\ Nancy Huang ${ }^{1}$, Luiz A. Bacheschi', Luiz E. Bacheschi', \\ Cláudia C. Leite1, Carlos A. Buchpiguel', Sérgio Rosemberg ${ }^{1}$
}

\begin{abstract}
High signal in the cerebral cortex and/or basal ganglia on diffusion-weighted magnetic resonance imaging (DW-MRI) has been described as a good diagnostic marker for sporadic Creutzfeldt-Jakob disease (sCJD). We report a case of SCJD with atypical clinical evolution and unusual DW-MRI findings. A 53-year-old man was seen with a 2-year history of a rapidly progressive dementia and cerebellar ataxia. Cerebrospinal fluid analysis, including the test for 14-3-3 protein, was normal. EEG did not show periodic activity. However, DW-MRI showed gyriform hyperintensity involving practically the entire cortical ribbon of the left hemisphere, whilst being limited to the posterior cingulate gyrus in the right hemisphere. DNA analysis showed no mutations or insertions in the prion protein gene, and homozigozity for methionine in codon 129. A subsequent brain biopsy confirmed the diagnosis of CJD. Thus, high signal on DW-MRI may be limited to the cerebral cortex and may present a very asymmetric distribution in SCJD.
\end{abstract}

KEY WORDS: Creutzfeldt-Jakob disease, prion disease, MRI, diffusion-weighted MRI.

\section{Hipersinal cortical assimétrico na ressonância magnética na imagem em difusão em caso de doença de Creutzfeldt-Jakob}

RESUMO - Hipersinal no cortex cerebral e/ou nos gânglios da base observado com a técnica de difusão da ressonância magnética (RM-DIF) tem sido descrito como bom marcador diagnóstico da doença de CreutzfeldtJakob esporádica (DCJe). Relatamos caso de DCJe com evolução clínica atípica e achados incomuns na RMDIF. Homem de 53 anos foi examinado com história de dois anos de demência rapidamente progressiva e ataxia cerebelar. Exame do líquido cefalorraqueano, incluindo pesquisa da proteína 14-3-3, foi normal; EEG não revelou atividade periódica; RM-DIF mostrou hiperintensidade nos giros que afetava quase inteiramente o manto cortical do hemisfério cerebral esquerdo e que no hemisfério direito se limitava à parte posterior do giro cíngulo. Análise do DNA revelou ausência de mutação ou de inserção no gene da proteína priônica e a presença de homozigose para metionina no códon 129. Biópsia cerebral confirmou o diagnóstico de DCJ. Hipersinal na RM-DIF pode ser limitado ao córtex cerebral e pode distribuir-se de modo muito assimétrico na DCJe.

PALAVRAS-CHAVE: doença de Creutzfeldt-Jakob, prion; ressonância magnética, difusão.

The clinical diagnosis of sporadic CreutzfeldtJakob disease (sCJD), particularly in its early manifestations, frequently presents a challenge to even the most experienced of neurologists. The clinical picture of most cases of SCJD is characterized by rapid progressive dementia, myoclonus, and multifocal neurological dysfunction, with a fatal outcome in the first one or two years after the onset of the symptoms. The presence of periodic sharp-wave complexes on the electroencephalogram (EEG) has been recognized as the most reliable non invasive test for the diagnosis of CJD'1 . However, this EEG a bno rmality may be absent in about one-third of the cases $^{2,3}$. There are cases of definite SCJD with a mo rerelentless pro $g$ ression and with atypical clinical features. Unfortunately, EEG periodic activity is usually absent in such cases ${ }^{2,3}$. Recently, two promising new diagnostic markers have become available: the assay for 14-3-3 protein in the cerebrospinal fluid (CSF) and the presence of abnormal high

\footnotetext{
${ }^{1}$ Hospital das Clínicas, University of São Paulo School of Medicine, São Paulo SP Brazil; ${ }^{2}$ Ludwig Institute for Cancer Research, São Paulo Branch, São Paulo SP, Brazil.
} 
intensity in the basal ganglia and/or in the cerebral cortex on diffusion-weighted magnetic resonance imaging (DW-MRI) ${ }^{4,5}$.

We report a case of SCJD with atypical clinical evolution and unusual findings in DW-MRI.

\section{CASE}

A 53-year old Brazilian born from Japanese parents and an electronics technician, was seen for the first time in Febru a ry 2003 with a 2-year history of behavioral disturbances and cognitive decline. Since 1991 he had been working in Japan as a foreign worker, while his family continued to live in Brazil. He had kept in touch with his family by mail or telephone, sending money to his wife practically every month. He had been retu ring once or twice a year to Brazil for vacations. In the beginning of 2001 he spent a vacation with his family, during which time he was considered to be a little more quiet than usual. In Februa ry2001 he retu med to Japan, and for the following six months did not contact his family in Brazil. His wife and sons became very worried and tried to contact him unsuccessfully. In August 2001 he was found by a friend, living homeless and in a very confuse state. He was brought back to Brazil in October 2001, and on arrival he was in a confused and apathetic state, refusing to wash or shave, but was partially independent for other daily activities, such as eating, still being able to control his sphincters. He was submitted to exhaustive medical and laboratory examinations which were inconclusive regardi$\mathrm{ng}$ the diagnosis. He was treated with paroxetine and became agitated and aggressive. Haloperidol $5 \mathrm{mg}$ bid associated with biperiden $2 \mathrm{mg}$ daily reduced the agitated and aggressive behavior, but he again became apathetic. The patient had been living in a nursing home since September 2002, since which time he had not been on medication. The subject's condition had continu- ed to deteriorate and in the few months prior to our first examination he had lost control of the sphincters. His past medical history was unremarkable whilst his mother had died with Alzheimer disease at the age of 93.

Physical examination was normal. On neurological examination the cranial nerves and muscle power were n o rmal, with brisk deep reflexes globally and flexor plantar reflexes bilaterally; muscle tone was slightly spastic in the legs. Gait was ataxic and a reduction of arm swinging was noticed on the left side. Ataxia was also present in finger to nose and heel to knee tests bilaterally. He did not show concern over his condition and when questioned about his memory replied that he did not know if it was normal or not. Echolalia was also present. He scored 8 points in the MMSE ( 2 in spatial orientation, 1 in registration, 2 in the verbal command, 2 in naming and 1 in repetition). Digit span was 3 in direct order and 0 in the reverse.

Routine laboratory tests, including haemogram, sedimentation rate, serum glucose, urea, creatinine, sodium, potassium, calcium, phosphorus, transaminases, B12 and folate levels, were normal, except for a slightly reduced thyroid-stimulating hormone level $(0.4 \mathrm{U} / \mathrm{ml}$; normal levels: 0.5-5.0 U/ml) with a normal free-T4 level. CSF analysis, including VDRL, TPHA and protein electrophoresis, were normal, and the test for 14-3-3 protein was negative. EEG showed diffuse disorganization of the electrical activity and epileptic activity in the right temporal region, without periodic activity.

Brain CT scan showed slight frontotemporal atrophy. Brain single-photon emission computed tomography (SPECT) revealed mildly reduced regional cerebral blood flow in left frontal, temporal-parietal and superior occipital regions. Quantitative analysis using Statistical Parametric Mapping (SPM-version 99) confirmed statistically significant $(p<0.001)$ hypoperfusion in left frontal region and left parietal regions. Additionally, SPM analy-

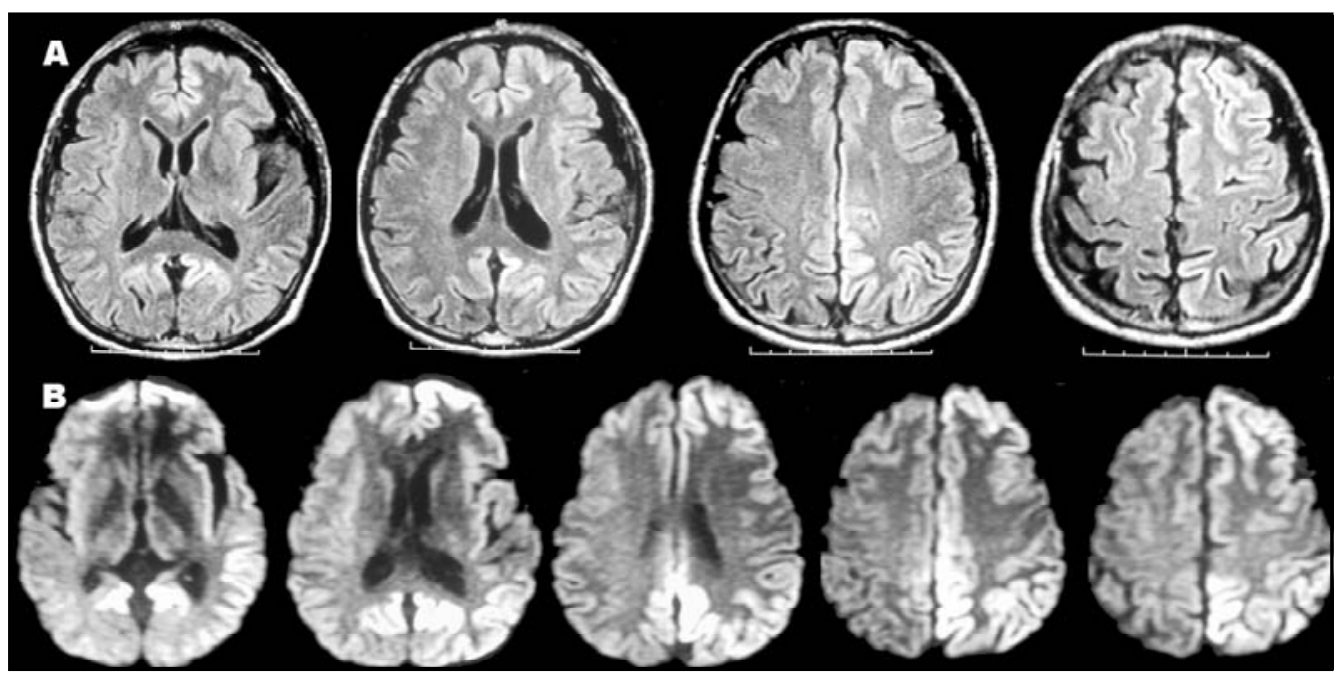

Fig 1. Brain MRI study showing gyriform hyperintensity on FLAIR (A) and diffusion-weighted images (B) involving the left cortical ribbon and the right posterior cingulate gyrus. 


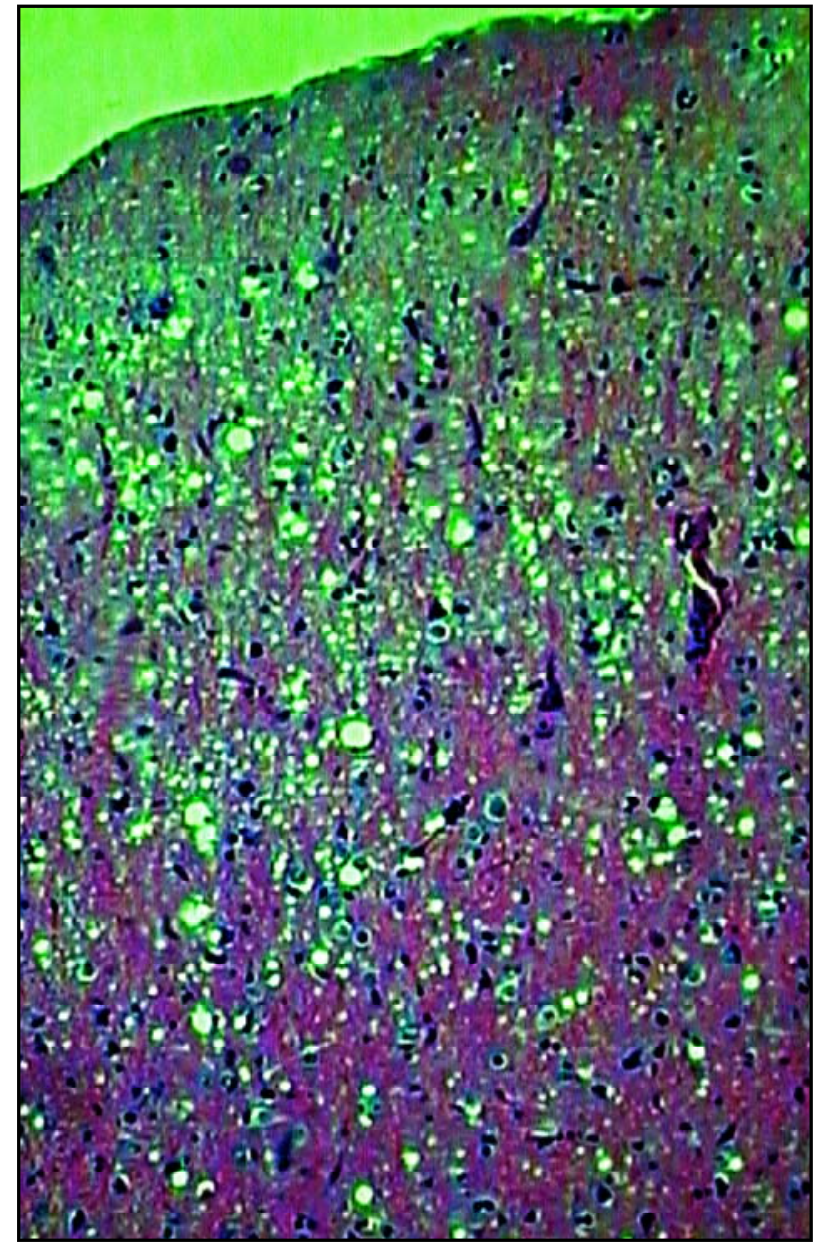

Fig 2. Cerebral cortex with moderate neuronal loss and spon giform change (HEX 250).

sis showed decreased blood flow in posterior cingular cortex and left cerebellum. Mild abnormalities in right occipital-parietal lobes did not survive on statistical analysis. Brain MRI study showed gyriform hyperintensity on fluid attenuated inversion recovery(FLAIR) and diffusion-weighted images involving almost entirely the cortical ribbon of the left hemisphere. In the right cerebral cortex, the hiperintensity was limited to the posterior cingulated gyrus (Fig 1).

A brain biopsy taken from the right superior frontal gyrus revealed neuronal loss, mild gliosis and spongiform change in the cerebral cortex (Fig 2). Immunohistochemistrywith 3F4 antibody showed scattered focal granular PrPRes deposits through the neuropil (Fig 3).

DNA analysis of peripheral blood cells using conventional sequencing or DHPLC ${ }^{6}$ showed no mutations or insertions in the prion protein gene, and the presence of 5 octarepeats, methionine in codon 129, asparagine in codon 171 and glutamic acid in codon 219 all in homozigozity.

His condition continued to worsen, but he was able to walk with assistance until the beginning of 2004. A

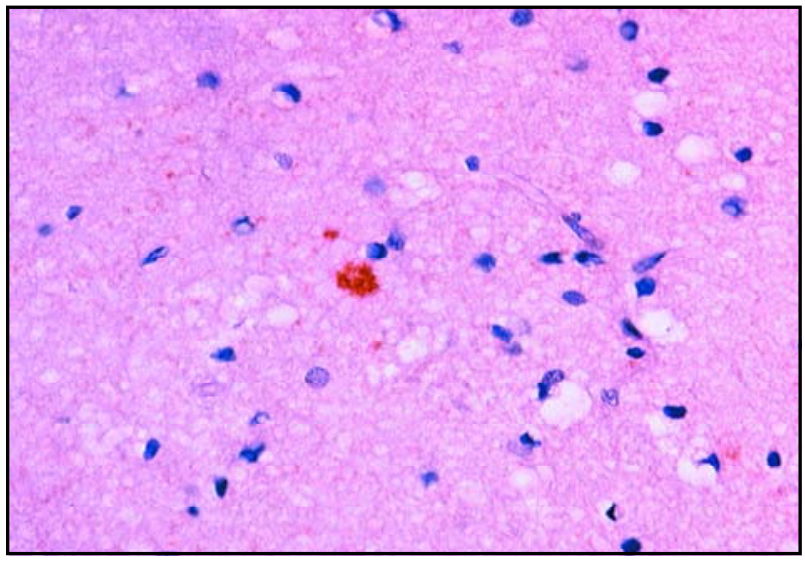

Fig 3. PrP positive granular deposits in the cerebral cortex (3F4 anti-PrP antibody).

year following the biopsy his condition had deteriorated to akinetic mutism.

\section{DISCUSSION}

According to the World Health Organization criteria, a typical EEG and/or a positive 14-3-3 CSF assay must be present for the diagnosis of probable SCJD 1 . Approximately $60-80 \%$ of cases of SCJD develop the characteristic EEG periodic activity ${ }^{1}$, and although the sensitivity of the detection of 14-3-3 in the CSF is usually very high in the typical cases of $\mathrm{SCJD}^{7}$, it may be in low in cases with nonclassic presentation ${ }^{8}$. In our case, a diagnosis of probable SCJD could not be assumed, a brain biopsy, however, confirmed this diagnosis. MR FLAIR images and DW-MRI showed abnormal high intensity in the cortical ribbon with a very asymmetric distribution, involving mainly the left side, and absence of hyperintensity in the basal ganglia.

The abnormal high intensity on DW-MRI in SCJD usually involves the striatum and/or the cerebral cortex ${ }^{9}$. It is possible that high signal on DW-MRI appears earlier in the cerebral cortex, while basal ganglia abnormalities appear later, when cortical high signals became less obvious $5^{5,10,11}$.The presence of high signal restricted to the cerebral cortex two years after the onset of the symptoms as seen in this case, is probably very uncommon. Asymmetric distribution had previously been reported ${ }^{10,12}$, and even unilateral cortical involvement has recently been described in a case of probable SCJD without pathological confirmation ${ }^{13}$. In several cases, correlation was found between high intensity in the cerebral cortex and clinical signs ${ }^{10,12}$, EEG abnomali$\operatorname{ties}^{12,14}$ or hypometabolism on PET-scan ${ }^{13,15}$. Except for the echolalia, the clinical signs did not suggest a more severe involvement of the left cerebral cor- 
tex in this case, while only brain SPECT showed correlation with the MRI findings.

The relatively long evolution raised the possibility of a familial form of CJD, which was excluded by DNA analysis. The clinical characteristics of the cases of SCJD have been related to the polymorphism in codon 129 and to the physicochemical properties of the protease-resistant prion protein $\left(\operatorname{Pr} P^{\mathrm{Sc}}\right)$ that is found in the brain ${ }^{16,17}$. There are two types or strains of PrPsc, types 1 and 2, and three possible genotypes at codon 129 [Methione homozigozity (MM), valine homozigozity (VV) and heterozigozity (MV)], which in conjunction are responsible for six CJD subtypes. The majority of sporadic cases of CJD are MM1 or MV1 ${ }^{17}$. Given that we did not ascertain the type of $\mathrm{PrP}^{\mathrm{Sc}}$, there are two possibilities for this case: MM1 or MM2. The clinical characteristics of MM1 cases are that of the typical SCJD, while MM2 cases may have a more protracted course and absence of EEG periodic activity ${ }^{17}$. The most distinctive pathological features of MM2 subtype are the type of spongiform degeneration, which is characterized by large, confluent vacuoles, along with the pattern of PrPSc staining, which is coarse ${ }^{17}$. In our case, the general pathological pattern was that found in most cases of SCJD with MM1 subtype.

Attempts to correlate MRI findings with these six subtypes have been made. A recent study demonstrated that DW-MRI abnormalities were pre sent in the first examination in 24 out of 26 patients with CJD'. The second DW-MRI showed high intensity lesions in the striatum in one of those patients, but repeated scans did not show abnormalities in the other patient, who was classified as MM2 (thalamic form) at post-mortem examination ${ }^{9}$. In another recent study, hyperintense signal changes in the basal ganglia were absent in the three patients classified as $\mathrm{MM}^{18}{ }^{18}$. In a reported case of MV2 subtype of SCJD, in which EEG periodic activity and 14-3-3 were negative, DW-MRI showed marked hyperintense signal abnormalities in the cerebral cortex and basal ganglia ${ }^{19}$. Recently, abnormal high intensity on DW-MRI has been seen in the thalamus in two cases of VV2-type of sCJD20. It is well known that hyperintense signal in the pulvinar is a typical sign of the variant CJD, which in turn is associated with bovine spongiform encephalopathy ${ }^{21}$. Taken together these data suggest that hyperintense signal changes in the brain on DW-MRI are frequent in all SCJD subtypes, except for the MM2 one.

In conclusion, MRI is a useful tool for the diagnosis of SCJD even when the presentation is atypi- cal and asymmetric cortical high signal may be found in this disease.

Acknowledgement - We are indebted to Dr. Françoise Gray for performing the immunohistochemical analysis.

\section{REFERENCES}

1. WHO. Report of the consultation on the global surveillance, diagnosi$\mathrm{s}$ and therapy of human transmissible spongiform encephalopathies. Geneva: WHO, 1998.

2. Zerr I, Pocchiari M, Collins S, et al. Analysis of EEG and CSF 14-3-3 protein as aids to the diagnosis of Creutzfeldt-Jakob disease. Neurology 2000;55:811-815.

3. Zeidler M, Green A. Advances in diagnosing Creutzfeldt-Jakob disease with MRI and CSF 14-3-3 analysis. Neurology 2004;63:410-411.

4. Hsich G, Kenney K, Gibbs CJ, Lee KH, Harrington MG. The 14-3-3 brain p rotein in cerebrospinal fluid as a marker for transmissible spongiform encephalopathies. N Engl J Med 1996;335:924-930.

5. Demaerel P, Baert AL, Vanopdenbosch L, Robberecht W, Dom R. Diffusion-weighted magnetic resonance imaging in Creutzfeldt-Jakob disease. Lancet 1997;349:847-848.

6. Castro RMRPS, Lamdenberger MC, Waltz R, et al. High capacity and low cost detection of prion protein gene variant alleles through denaturing HPLC methodology. J Neurosc Meth 2004;62:751-755.

7. Zerr I, Bodemer M, Gefeller O, et al. Detection of 14-3-3 protein in the cere b rospinal fluid supports the diagnosis of Creutzfeldt-Jakob disease. Ann Neurol 1998;43:32-40.

8. Castellani, RJ, Colucci M, Xie Z, et al. Sensitivity of 14-3-3 protein test varies in subtypes of sporadic Creutzfeldt-Jakob disease. Neurology 2004;63:436-442.

9. Shiga Y, Miyazawa K, Sato S, et al. Diffusion-weighted MRI abnormalities as an early diagnostic marker for Creutzfeldt-Jakob disease. Neurology 2004;63:443-449.

10. Yee AS, Simon JH, Anderson CA, Sze CI, Filley CM. Diffusion-weighted MRI of right-hemisphere dysfunction in Creutzfeldt-Jakob disease. Neurology 1999;52:1514-1515.

11. Tribl GG, Strasser G, Zeitlhofer J, et al. Sequential MRI in a case of Creutzfeldt-Jakob disease. Neuroradiology 2002;44:223-226.

12. Cambier DM, Kantarci K, Worrell GA, Westmoreland BF, Aksamit AJ. Lateralized and focal clinical, EEG, and FLAIR MRI abnormalities in Creutzfeldt-Jakob disease. Clin Neurophysiol 2003;114:1724-1728.

13. Bavis J, Reynolds P, Tegeler C, Clark P. Asymmetric neuroimaging in Creutzfeldt-Jakob disease. J Neuroimaging 2003;13:376-379.

14. Mao-Draayer Y, Braff SP, Nagle KJ, Pendlebury W, Penar PL, Shapiro RE. Emerging patterns of diffusion-weighted MR imaging in CreutzfeldtJakob disease: case report and review of the literature. Am J Neuroradiol 2002;23:550-556.

15. Tsuji Y, Kanamori H, Murakami G, et al. Heidenhain variant of Creutzfeldt-Jakob disease: diffusion-weighted MRI and PET characteristics. J Neuroimaging 2004;14:63-66.

16. Parchi P, Castellani R, Capellari S, et al. Molecular basis of phenotypic variability in sporadic Creutzfeldt-Jakob disease. Ann Neurol 1996; 39:767-778.

17. Parchi P, Giese A, CapellariS, et al. Classification of sporadic CreutzfeldtJakob disease based on molecular and phenotype analysis of $300 \mathrm{sub}-$ jects. Ann Neurol 1999;46:224-233.

18. Meissner B, Köhler K, Körtner K, et al. Sporadic Creutzfeldt-Jakob disease: magnetic resonance imaging and clinical findings. Neurology 2004; 63:450-456.

19. Samman I, Schulz-Schaeffer WJ, Wohrle JC, Sommer A, Kretzschmar HA, Hennerici M. Clinical range and MRI in Creutzfeldt-Jakob disease with heterozygosity at codon 129 and prion protein type 2. J Neurol Neurosurg Psychiatry 1999;67:678-681.

20. Fukushima R, Shiga Y, Nakamura M, Fujimori J, Kitamoto T, Yoshida Y. MRI characteristics of sporadic CJD with valine homozygosity at codon 129 of the prion protein gene and PrPSc type 2 in Japan. J Neurol Neurosurg Psychiatry 2004;75:485-487.

21. Collie DA, Summers DM, Sellar RJ, et al. Diagnosing variant CreutzfeldtJakob disease with the pulvinar sign: MR imaging findings in 86 neuropathologically confirmed cases. Am J Neuroradiology 2003;24:1560-1569 